\title{
Çocukları Okul Öncesi Eğitim Kurumlarına Devam Eden Ebeveynlerin Tutumlarının İncelenmesi ${ }^{1}$
}

\author{
Nur UYGUN² ve İshak KOZİKOĞLU ${ }^{3}$
}

Öz

Bu araştırmanın amacı, 2017-2018 öğretim yılında MEB’e bağlı okul öncesi eğitim kurumlarına devam eden çocukların ebeveynlerinin tutumlarını incelemektir. $\mathrm{Bu}$ araştırmada, betimsel tarama modeli kullanılmıştır. Araştırmanın örneklemini, tabakalı örnekleme yöntemi kullanılarak belirlenen 521 ebeveyn oluşturmaktadır. Araştırmada, ebeveynlerin tutumlarını belirmek için "Ebeveyn Tutum Ölçeği” kullanılmıştır. Araştırma verilerinin analizinde betimsel istatistikler (ortalama, standart sapma) ve fark analizleri (ANOVA, MANOVA) kullanılmıştır. Araştırmanın sonucunda, çocukların ebeveynlerinin en fazla demokratik tutumu ve aşırı koruyucu tutumu benimsedikleri, otoriter ve izin verici tutumu daha az benimsedikleri sonucuna ulaşılmıştır. Çocuk sayısı arttıkça ebeveynlerde demokratik tutumun azaldığı, ebeveynlerin eğitim ve gelir düzeyi yükseldikçe demokratik tutumu daha fazla benimsedikleri, otoriter ve aşırı koruyucu tutumu ise daha az benimsedikleri sonucuna ulaşılmıştır. Ebeveynlerin doğru tutumu benimseyebilmeleri için çocuk yetiştirme tutumları ile ilgili seminer, kurs, anne-baba eğitim programlarının hazırlanması önerilebilir. Ayrıca, bu eğitimler sayesinde çocuğun iyiliği için yaptığını düşünen fakat farkında olmadan bağımlı ve özgüveni düşük birey yetiştiren aşırı koruyucu tutum sergileyen ebeveynlerin doğru tutum olan demokratik tutumu benimsemeleri sağlanabilir.

Anabtar Kelimeler: Ebeveyn tutumları, Demokratik tutum, Otoriter tutum, İzin verici tutum, Aşırı koruyucu tutum

\section{The Investigation of Attitudes of Parents Whose Children Are Preschoolers}

\section{Abstract}

The aim of this study is to determine parental attitudes of parents whose children attend preschool education institutions affiliated to the Ministry of National Education in the 2017-2018 academic year. In this study, descriptive survey model was used. The sample of the study consists of 521 parents that were determined by stratified sampling method. In this study, "Parental Attitude Scale" was used to identify parents' attitudes. In the analysis of research data, descriptive statistics (mean, standard deviation) and differential statistics (ANOVA, MANOVA) were used. As a result of study, it was concluded that the parents of the children exhibit democratic and over-protective parental attitudes at most, respectively. They exhibit permissive and authoritarian attitudes at least, respectively. As the number of children increases, the democratic attitude decreases; as the parents' level of education and income increase, the parents adopt the democratic attitude more, but the authoritarian and over-protective attitude are adopted less. In order for parents to adopt the right attitude, it is advisable to prepare seminars, courses and parent education programs on child growing attitudes. In addition, through these trainings, parents who adopt an overprotective attitude who think that they are doing for the sake of the child, but who are not aware of it, can be provided with the right attitude to adopt the democratic attitude.

Key Words: Parental attitudes, Democratic attitude, Authoritarian attitude, Permissive attitude, Over-protective attitude

\section{Atıf İçin / Please Cite As:}

Uygun, N. ve Kozikoğlu, İ. (2020). Çocukları okul öncesi eğitim kurumlarına devam eden ebeveynlerin tutumlarının incelenmesi. Manas Sosyal Arașttrmalar Dergisi, 9(3), 1494-1507.

Geliş Tarihi / Received Date: 28.10.2019

Kabul Tarihi / Accepted Date: 18.12.2019

\footnotetext{
${ }^{1}$ Bu çalışma, ilk yazarın "Okul Öncesi Eğitim Kurumlarna Devam Eden Çocuklarn Oyun Davranısları, Sosyal Yetkinlik Davranışları ve Ebeveyn Tutumlar Arasındaki İlişkel” başliklı yüksek lisans tezinden üretilmiştir.

2 Öğretmen - Van- Türkiye, nuruygun.13@gmail.com - ORCID: 0000-0002-8599-6796

${ }^{3}$ Doç. Dr. - Van Yüzüncü Yil Üniversitesi Eğitim Fakültesi, ishakkozikoglu@yyu.edu.tr

ORCID: 0000-0003-3772-4179
} 


\section{Giriş}

Anne, baba ve çocuk arasındaki ilişkiyi ilk olarak antropologlar incelemiştir. Antropologlar ebeveynin çocukla günlük etkileşimi, bakımı, aile arasındaki rol dağılımı ve ebeveynin ilgi, deneyim ve kültürü kendi çocuklarına nasıl aktardığını incelemişlerdir. Daha sonra yapılan psikolojik çalışmalar ebeveyn tutum ve davranışlarının çocuğun gelişimi üzerindeki etkilerini araştırmışlardır. Özellikle çocuğun gelişiminde daha fazla sorumluluk üstlenen anneler ile çocuk arasındaki iletişim incelenerek çocuğun kişilik ve ruhsal sorunlarının annelerin tutum ve davranışlarından kaynaklandığı belirlenmiştir (Özgün, 2013, s. 73-76). Zamanla anne tutumları kadar baba tutumlarının da çocuk üzerinde belirleyici bir etkiye sahip olabileceği düşünülerek bu konuyla ilgili çalışmalar günümüzde de önemini korumaktadır.

Çocukların sosyal-duygusal gelişimleri, içinde bulundukları ortamdan ve iletişim kurdukları kişilerden etkilenebilmektedir. Çocuğun karşılaştı̆̆ı, iletişim kurduğu ve uyum sağlamaya çalıştığ ilk sosyal ortam ailedir. Toplumun temelini oluşturan ailenin çocuğun beslenme, eğitim ve tüm gelişimsel ihtiyaçlarını karşılamak gibi sorumlulukları vardır. Bu sorumlulukları sevgi, saygı, ilgi, hoşgörü ile yerine getirmesi aile içi huzuru artıracaktır (Ünal, 2013, s. 2). Çoğu ebeveyn, çocuklarının toplumun kabul ettiği değerleri benimsemesi ve çağın gerektirdiği bilgi ve beceri düzeyine sahip olması için birçok strateji uygulamaktadır. Ayrıca ebeveynlerin çocuklarının gelecekte nasıl biri olacağına ve hangi mesleği yapacağına dair beklentileri vardır. $\mathrm{Bu}$ beklentiler doğrultusunda ebeveynler farklı yollar uygulamaktadırlar. Bazı ebeveynler, çocuklarına istendik davranışları sergilemeleri için pekiştireç ve ceza uygularken bazı ebeveynler beklentilerini açıklamakta, çocukları için arkadaş grupları ve okullar seçmektedirler. Bu farklı uygulamalar ebeveynlerin benimsemiş olduğu tutumlardan kaynaklanmaktadır (Mussen vd., 1984, s. 541). Ebeveyn tutumları ise ebeveynlerin kişisel özelliklerinden, inançlarından, düşüncelerinden ve çocuklarının mizaç özelliklerinden etkilenmektedir (Yavuzer ve Demir, 2016, s. 65-66).

Ebeveynlerin çocuklarla güven ve sevgiye dayalı bağ kurması, çocukları sosyal açıdan olumlu yönde etkilemekte ve çevresiyle etkili iletişim kurmasını sağlamaktadır. Böylece çocuklar arkadaşlarıyla daha rahat iletişim kurabilmekte ve etkileşim içinde oldukları tüm insanlara karşı ilgili, duyarlı ve destekleyici olmaktadırlar. Olumlu benliğe sahip olan bu çocuklar, gelecekte bütün sosyal ortamlarda kendilerini, duygu ve düşüncelerini ifade edebilen, özgüveni yüksek, bireysel ve toplumsal gelişim için gereken sorumlulukları üstelenen bireyler olmaktadırlar. Ebeveynlerin kaygı ve korkuya dayanan olumsuz tutumlarıyla yetişen çocuklar ise kendilerini girdikleri ortamlardan dışlanmış olarak hissederler. Bu kayg1 ve korku duygusuyla kendini ifade etmekten çekinen çocuklar, sosyal çevreyle ilişki kurmak yerine kendi içine yönelme veya bu duyguyu öfkeyle dışa vurarak saldırgan davranışlar sergileme eğiliminde olurlar (Rubin, Bukowski ve Parker, 2006, s. 580-590).

Maccoby ve Martin (1983, s. 38-39) ebeveyn tutumlarını, ilgi/kabul ve talep boyutlarının yüksek ve düşük olmasina göre dört gruba ayırmıştır. Demokratik tutumu benimseyen ebeveynler, talep ve kabul etmede yüksek olan ebeveynlerdir. Otoriter ebeveynler, talep etmede yüksek buna karşıı kabul etmede düşük olan ebeveynlerdir. Kabul etmede yüksek ve talep etmede düşük olan ebeveynler iæin verici tutumu benimseyen ebeveynlerdir. İhmalkâr ebeveynler ise hem talep etmede hem de kabul etmede düşük olan ebeveynlerdir. Baumrind yaptığı birçok araştırma sonucunda, 1980 yılında ebeveyn tutumlarını otoriter, demokratik ve hoşgörülü olmak üzere üç gruba ayırmıştır (Santrock, 1997, s. 78). Görüldüğü üzere, ebeveyn tutumları farklı şekillerde gruplandırılmaktadır. Bu araştırmada ebeveyn tutumları, araştırmada kullanılan "Ebeveyn Tutumları Ölçeği”"nde ele alınan ve alanyazında da kabul gören haliyle demokratik tutum, otoriter tutum, aşırı koruyucu tutum ve izin verici tutum olmak üzere dört boyutta ele alınmıştır.

\section{Demokratik Tutum}

Demokratik ebeveyn tutumunda ebeveynler, kontrollü bir şekilde çocukların bağımsız olmasını desteklemektedirler. Çocukların isteklerine duyarlı olan ebeveynler, aile içinde alınacak kararlarda çocukların fikrini de önemsemektedirler. Aile içindeki her bireyin hak ve sorumlulukları dikkate alınarak uyulması gereken kurallar belirlenmiștir. Çocuklardan bu kurallara ödül ve ceza uygulamadan uymaları beklenir. Anne-babalar çocuklarının gelişimsel ihtiyaçlarını karşılamaya ve çocuklarla olumlu iletişim kurmaya önem verirler (Erkan, 2013, s. 13; Özkafac1, 2012, s. 6). Demokratik ebeveynler, çocuklarının bireysel özelliklerinin farkındadır ve onların isteklerini, düşüncelerini ifade etmelerine destek olurlar (Yavuzer, 2003, s. 26-30). 


\section{Otoriter Tutum}

Otoriter ebeveyn tutumunda ebeveynler, çocukların isteklerine karşı duyarlı değillerdir. Çocuklarının kendilerine sayg1 göstermelerini, kendi belirledikleri kurallara sorgulamadan itaat etmelerini beklerler. Çocuklarına güvenmeyen ebeveynler, istenmeyen davranışlarla karşılaştıklarında cezaya başvururlar. Çocukları olumlu davranış gösterdiklerinde ise ödüllendirmezler (Erkan, 2013, s. 12; Santrock, 1997, s. 78). Çocuğun gelişim düzeyi dikkate alınmadan kendi beklentileri doğrultusunda çocuklarının davranmasını beklerler. Aile içindeki otoritenin sağlanmasına önem veren bu ebeveynler, çocuklarının bu duruma karşı çıkmalarını veya değiştirme çabalarını cezalar ile hemen bastırırlar. Otoriter ebeveynler, çocuklarına gereken ilgi ve sevgiyi göstermezler (Maccoby ve Martin, 1983, s. 38-39).

\section{Aşırı Koruyucu Tutum}

Aşırı koruyucu tutum sergileyen ebeveynler, çocuklarının gelişimini sınırlandıracak ölçüde çocuklarını tehlikelerden korumaya, kontrol altında tutmaya çalışırlar. Çocuklarına derin duygularla bağlandıkları için sebepsiz kaygı yaşarlar. Çocukları yerine karar vererek onları koruduklarını düşünmektedirler. Hayatı çocukları için kolaylaştırmaya çalışan ebeveynlerin çocuktan bir beklentileri yoktur, her şeyi onların yerine yapmaktadirlar (Erkan, 2013, s. 10-12; Karabulut Demir ve Şendil, 2008, s. 23; Maccoby ve Martin, 1983, s. 38-39). Çocuğun gelişimsel düzeyine göre yapması belenen tüm davranışları çocuk yorulmasın, incinmesin ya da o yapamaz düşüncesiyle ebeveynler kendisi yapmaktadırlar. Aşırı sevgi ve ilgiden kaynaklı olsa bile tüm bu davranışlar çocuğun gelişimine kısıtlamalar getirdiği için çocuğun beklenen düzeyde beceri kazanmasını engellenmektedir (Özyürek ve Tezel-Şahin, 2010, s. 48).

\section{İzin Verici Tutum}

İzin verici tutuma sahip ebeveynler, genellikle kendi çocukluk döneminde aşırı disipline maruz kalmış, kendi ebeveynlerinden yeteri kadar sevgi görememiş ebeveynlerdir. Ayrıca, anne-babanın iş yoğunluğundan, çocuğuyla yeterince vakit geçirmemesinden kaynaklanan suçluluk duygusundan dolay1 çocuklarının her istediğini yerine getirme eğiliminde olabilirler (Çağdaş ve Seçer, 2011, Yavuzer, 2011, s. 26-33). İzin verici ebeveyn tutumunu benimseyen ebeveyn, çocuğun her dediğini yerine getirmeye çalışmakta, çocukları tarafindan yönetilmektedir (Yavuzer, 2011, s. 26-33). Çocukların saldırgan davranışları dâhil hiçbir davranışına sınırlama getirmezler. Yeme ve uyku düzenini oluşturmaya çalışmazlar, çocuğun isteğine birakırlar (Erkan, 2013, s. 10-13; Altay ve Güre 2012, s. 1-3). İzin verici ebeveyn tutumuna sahip ebeveynler, genellikle çă̆daş eğitim modelini uyguladıklarını düşünmektedirler. Bazen çocuklarına karşı kural koymaları gerektiğini düşünseler de kararsız kaldıkları için çocukları anne babalarının bu duruşundan etkilenmezler (Yörükoğlu, 1987).

Ebeveyn tutumunun çocuğun yaratıcı düşünme, eleştirel düşünme, problem çözme gibi bilişsel gelişiminin yanı sıra çocuğun kendini tanıması, ifade edebilmesi, olumlu benlik algısı geliştirmesi, çevresine güven duyması, diğer bireylerle iletişime geçmesi, toplumsal kuralları öğrenmesi, içinde bulunduğu toplumla uyum içinde yaşaması ve sosyal gelişimi üzerinde etkisi vardır (Özkafac1, 2012, s.2-3; Özbey, 2010, s.15-16; Tezel, Şahin ve Cevher, 2007, s.785-786). Dolayısıyla, özellikle eğitim sürecinin ilk kademesi olarak bilinen okul öncesi eğitim kurumlarında öğrenim gören çocukları olan ebeveynlerin ebeveyn tutumlarının belirlenmesi önemli görülmektedir.

\section{Araştırmanın Amacı ve Önemi}

Bu araştırmanın amac1, 2017-2018 öğretim yılında MEB’e bağlı okul öncesi eğitim kurumlarına devam eden çocukların ebeveynlerinin ebeveyn tutumlarını incelemektir. Bu amaç doğrultusunda aşağıdaki sorulara yanıt aranmıştır:

1. Okul öncesi eğitim kurumlarına devam eden çocukların ebeveynlerinin ebeveyn tutumları nelerdir?

2. Okul öncesi eğitim kurumlarına devam eden çocukların ebeveynlerinin ebeveyn tutumları çocuk sayısına, ebeveyn eğitim düzeyine ve ailenin gelir düzeyine göre anlamlı farklılık göstermekte midir?

Çocuğun kendini ve içinde bulunduğu toplumu tanıması, uyum içinde yaşaması ve sosyal gelişimini sağlıklı şekilde tamamlaması üzerinde ebeveyn tutumunun önemli bir etkisi vardır. Yaşanan toplumsal gelişmeler çocuğun hem şimdiki yaşamını hem de gelecekteki yaşamını şekillendiren ebeveyn tutumlarını da değiştirmiştir. Ebeveyn tutumları değişmesine rağmen çocuğun gelişimindeki önemi devam etmektedir (Erkan, 2013, s. 10). Bu nedenle yaşamsal öneme sahip olan çocukluk döneminin niteliğini arttırmak için ebeveyn tutumlarının belirlenmesine ihtiyaç duyulmaktadır. Dolayısıyla, bu çalışma okul öncesi eğitim 
kurumlarına devam eden çocukların ebeveynlerinin ebeveyn tutumlarını belirlemesi açısından önem taşımaktadır. Ayrıca çocuk sayısı, ebeveyn eğitim düzeyi ve aile gelir düzeyi gibi değişkenlere göre ebeveynlerin ebeveyn tutumlarının farklılaşıp farklılaşmadığını ortaya koyması yönüyle bu çalışmanın ilgili alanyazına katkı sağlayacağ1 düşünülmektedir.

\section{Yöntem}

\section{Araştırmanın Modeli}

$\mathrm{Bu}$ araştırmada, betimsel tarama modeli kullanılmıştır. Betimsel tarama modellerinde mevcut olgu, kişi veya durumların mevcut durumuyla ortaya konulması hedeflendiği için (Karasar, 2015, s. 77), çocuğu okul öncesi eğitim kurumlarına devam eden ebeveynlerin ebeveyn tutumlarının incelendiği bu araştırmanın amacına uygun olduğu düşünülmektedir.

\section{Evren ve Örneklem}

Bu araştırmanın çalışma evrenini, 2017-2018 eğitim-öğretim yllında Van İli İpekyolu, Tuşba ve Edremit merkez ilçelerinde bulunan Milli Eğitim Bakanlı̆̆ına bağlı okul öncesi eğitim kurumlarında eğitim gören çocukların ebeveynleri oluşturmaktadır. Bu durumda, öncelikle okul öncesi eğitim kurumlarında eğitim gören çocuklar belirlenmiş ve çocuklar aracılı̆̆ıyla onların ebeveynlerine ulaşılmıştır. Van İl Milli Eğitim Müdürlüğünden alınan verilere göre; İpekyolu ilçesinde 6286, Tuşba ilçesinde 2779, Edremit ilçesinde ise 3118 çocuk olmak üzere Van ilinin belirtilen üç merkez ilçesinde toplam 12.183 çocuk MEB'e bağlı okul öncesi eğitim kurumlarında eğitim görmektedir. Bu çalışmada, çalışma evreninin tamamına ulaşmak zaman, emek ve olanaklar bakımından güç olduğu için örneklem alma yoluna gidilmiştir. Araştırmada tabakalı örnekleme yöntemi kullanılmıştır. Tabakalı örneklemede; araştırmayı etkileyecek çeşitli faktörler düşünülerek evren bu faktörler doğrultusunda alt gruplara ayrılmakta ve her gruptan belirli oranda seçkisiz olarak örneklem alınmaktadır (Padem Göksu ve Konaklı, 2012, s. 87-89). Dolayısıyla bu araştırmada, ebeveynlerin ebeveyn tutumları üzerinde etkili olabileceği düşüncesiyle belirlenen ilçelerde yer alan okul öncesi kurumları uzman görüşü alınarak alt, orta ve yüksek sosyo-ekonomik gelişmişlik düzeyi olmak üzere üç tabakaya ayrılmıştır. Her bir tabakadan belirli sayıda okul öncesi kurumu seçkisiz olarak belirlenmiş ve belirlenen okul öncesi kurumlarında eğitim gören çocukların ebeveynlerine ulaşılmıştır.

Örneklem büyüklüğünün belirlenmesinde, zaman ve olanaklar bakımından mümkün olabildiğince daha geniş ve evreni temsil edebilecek güçte bir örneklem belirlemek önem taşımaktadır (Fraenkel, Wallen ve Hyun, 2012, s. 102). Bu araştırmada, araştırmanın evrenini olabildiğince yüksek düzeyde temsil edebilmesi açısından araştırmanın amacına uygun olacak şekilde örnekleme alınan ebeveyn sayısının yüksek tutulması amaçlanmıştır. Dolayısıyla, belirlenen okul öncesi kurumlarında öğrenim görmekte olan 3 ilçeden toplam 521 çocuğun ebeveyni araştırmanın örneklemini oluşturmuştur. İlçelere göre örneklem alınırken çalışma evrenindeki oranı dikkate alınmıştır. Çıngı’ya (1994) göre, “.05” anlamlılık düzeyinde evren sayısının 10.000 olması durumunda örneklem sayısının 370 olması evreni temsil etme bakımından yeterli görülmektedir (Akt: Büyüköztürk ve diğerleri, 2012, s. 98). Bu durumda, bu çalişmanın örnekleminin evreni temsil edebilecek büyüklükte olduğu söylenebilir. Araştırmanın örneklemini oluşturan okul öncesi eğitim kurumlarına devam eden çocukların ebeveynlerinin cinsiyete, eğitim düzeyine, çocuk sayısına ve gelir düzeyine göre dağılımı Tablo 1'de verilmiştir.

Tablo 1. Örneklemde Yer Alan Cocuklarn Ebeveynlerinin Cinsiyete, Eğitim Düzeyine, Cocuk Sayzsna ve Gelir Düreyine Göre Dă̆llımı

\begin{tabular}{|c|c|c|c|}
\hline Özellik & Kategori & Sayı (N) & Yüzde (\%) \\
\hline \multirow{2}{*}{ Cinsiyet } & Kadin (Anne) & 493 & 95 \\
\hline & Erkek (Baba) & 28 & 5 \\
\hline \multirow{5}{*}{ Eğitim düzeyi } & Okur-yazar değil & 50 & 10 \\
\hline & İlkokul & 171 & 33 \\
\hline & Ortaokul & 108 & 21 \\
\hline & Lise & 111 & 21 \\
\hline & Üniversite & 81 & 15 \\
\hline \multirow{4}{*}{ Çocuk sayısı } & 1 çocuk & 55 & 11 \\
\hline & 2 çocuk & 237 & 46 \\
\hline & 3 çocuk & 133 & 25 \\
\hline & 4 ve üzeri & 96 & 18 \\
\hline \multirow{5}{*}{ Gelir düzeyi } & $0-1499 \mathrm{TL}$ & 181 & 35 \\
\hline & $1500-2499 \mathrm{TL}$ & 149 & 28 \\
\hline & 2500-3499 TL & 82 & 16 \\
\hline & 3500 TL ve üzeri & 109 & 21 \\
\hline & Toplam & 521 & 100 \\
\hline
\end{tabular}


Tablo 3 verilerine göre, çalıșmaya katılan ebeveynlerin 493’ü (\%95) anne ve $28{ }^{\prime} \mathrm{i}(\% 5)$ ise babadır. Ebeveynlerin 50'si (\%10) okuryazar değil, 171'i (\%33) ilkokul mezunu, 108'i (\%21) ortaokul mezunu, 111'i $(\% 21)$ lise mezunu ve 81’i (\%15) ise üniversite mezunudur. Ebeveynlerin 55\%i (\%11) 1 çocuğa, 237’si (\%46) 2 çocuğa, 133’ü (\%25) 3 çocuğa ve 96’s1 (\%18) 4 ve üzeri çocuğa sahiptir. Ailelerin gelir düzeyi incelendiğinde ise ailelerin 181'i (\%35) 0-1499 TL arası aylık gelire, 149’u (\%28) 1500-2499 TL arası aylik gelire, 82’si (\%16) 2500-3499 TL arası aylık gelire, 109’u (\%21) ise 3500 TL ve üzeri aylık gelire sahiptir.

\section{Veri Toplama Araçları}

Araştırmada, okul öncesi eğitim kurumlarına devam eden çocukların ebeveynlerinin ebeveyn tutumlarını belirlemek amacıyla "Ebeveyn Tutum Ölçeği” kullanılmıştır. Karabulut Demir ve Şendil (2008) tarafindan anne-babaların okul öncesi dönem çocuklarını yetiştirirken gösterdikleri ebeveynlik tutumlarını belirlemek amacıyla geliştirilen ve beşli Likert formatında olan ölçek; "demokratik", "otoriter", "aşırı koruyucu" ve "izin verici" olmak üzere dört alt boyuttan oluşmaktadır. Ölçek; "demokratik" tutum boyutu 17 madde, "otoriter" tutum boyutu 11 madde, "aşır1 koruyucu" tutum boyutu 9 madde, "izin verici" tutum boyutu 9 madde olmak üzere toplam 46 maddeden oluşmaktadır. Ölçeğin Cronbach Alpha iç güvenirlik katsayıları "demokratik" alt boyutu için .83, "otoriter" alt boyutu için .76, "aşır1 koruyucu" alt boyutu için .75 ve "izin verici" alt boyutu için ise .74 olarak hesaplanmıştır. Bu çalş̧mada ise ölçeğin Cronbach Alpha iç güvenirlik katsayıları demokratik alt boyut için .82, otoriter alt boyutu için .81, aşırı koruyucu alt boyutu için .75 ve izin verici alt boyutu için ise .71 olarak hesaplanmışır. Bu değerler, ölçeğin geçerli ve güvenilir bir ölçme aracı olduğunu göstermektedir.

Veri toplama sürecinde, belirlenen ilçelerdeki okullar uzman görüşü alınarak alt, orta ve yüksek sosyoekonomik gelişmişlik düzeyi olmak üzere üç tabakaya ayrılmıştır ve her bir tabakadan belirli sayıda olmak üzere toplam 25 okul öncesi kurumu (MEB’e bağlı bağımsız anaokulları ve ilkokul bünyesindeki anasınıfları) seçkisiz olarak belirlenmiştir. İzin belgeleri ve veri toplama araçları ile birlikte uygulama yapılacak okullara tek tek gidilmiş ve ölçeklerin ebeveynlere uygulanması için okul yönetiminin onayı alınmıştır. Okullarda öğretmenler ve yöneticilerle görüşülerek ölçek uygulamasına ilişkin genel bilgi ve yönergeler açılanmıştır. Her öğretmenden sınıf listesinden 4 kız 4 erkek olmak üzere seçkisiz olarak 8 çocuk seçmesi istenmiştir. Seçilen çocukların ebeveynlerine doldurmaları için ebeveyn tutum ölçeği öğretmenler ve okul yönetimi aracıllğıyla ebeveynlere ulaştırılmıştır.

\section{Verilerin Analizi}

Araştırmada okul öncesi eğitim kurumlarına devam eden çocukların ebeveynlerinin ebeveyn tutumlarını belirlemek için ölçek puanlarına ilişkin aritmetik ortalama ve standart sapma değerleri incelenmiştir. Ebeveyn tutumları için alt boyutlarda ortalamanın yüksek olması ebeveynin ilgili tutumu daha çok benimsediği, düşük olması ise daha az benimsediği şeklinde yorumlanmıştır.

Çocukların ebeveynlerinin ebeveyn tutumlarının ise çocuk sayısı, eğitim düzeyi ve ailenin gelir düzeyine göre anlamlı farklılık gösterip göstermediğine ilişkin çok değişkenli varyans analizi (MANOVA) kullanılmıştır. MANOVA sonuçlanı anlamlı çıkması durumunda tek yönlü varyans analizi (ANOVA) yapılabilir (Field, 2009 Akt: Aypay, Çekiç ve Seçkin, 2012, s. 1345-1366). Bu durumda, MANOVA testi sonuçlarında anlamlı fark çıkması üzerine belirlenen değişkenlere göre grup ortalamalarının nasıl farklılık gösterdiğini ortaya koymak amacıyla ANOVA testi uygulanmıştır. Analizlerde anlamlilık düzeyi .05 olarak belirlenmiştir. MANOVA testinin ".05" düzeyinde anlamlı çıkması durumunda yapılan ANOVA testlerinde I.tip hatayı önlemek için Bonferroni düzeltmesi (correction) yapılmışıtır. Bonferroni düzeltmesinde, anlamllık düzeyi bağımlı değişken sayısına bölünmektedir (Miller, 1991, s. 189-210). Bu durumda, anlamlılık düzeyi Bonferroni düzeltmesi ile ebeveyn tutum ölçeğinin alt boyutları için ".0125 (.05/4)" olarak belirlenmiştir (Büyüköztürk, 2013, s. 148). Ayrıca, ANOVA testinde yapılan karşılaştırma sonucunda anlamlı fark çıkması durumunda, farkın kaynağını belirlemek için çoklu karşılaştırma testlerinden Scheffe testi kullanılmıştır.

Analizler öncesinde, MANOVA testinin yapılabilmesi için gerekli olan varsayımlar ele alınmıştır. Bu doğrultuda, araştırma verilerine ilişkin doğrusallık, tek ve çok değişkenli normallik, varyans-kovaryans matrisinin homojenliği ve çoklu bağlantı problemi olup olmadığ1 incelenmiştir (Büyüköztürk, 2013, s. 148; Pallant, 2005, s. 249). Tek değişkenli normallik için bağımlı değişkenlere ait histogram grafikleri incelenmiş, ayrıca çarpıklık ve basıklık değerlerine bakılmıştır. Bunun sonucunda, ebeveyn tutumları ölçeğinde bağımlı değişkenlere ait puanların çarpıklık (skewness) değerlerinin 0.615 ile 0.961 arasında değiştiği, basıklık (kurtosis) değerlerinin ise -0.247 ile 0.984 arasında değiştiği belirlenmiştir. Bu durumda, bağımlı değişkenlere ait puanlara ilişkin çarpıklık ve basıklık katsayılarının \pm 1 aralığında olduğu dikkate alınarak ve 
histogram grafiklerine bakılarak verilerin normal dağılım gösterdiği kabul edilmiştir (Büyüköztürk, 2013, s. 21-23). Varyansların homojenliği için Levene's Test ve Kovaryans matrislerinin dağılımı için ise Box's M sonuçları incelenmiştir. Yapılan analizler sonucunda, bu sonuçların istatistiksel olarak anlamlı olmadığ (p>.05) ve dolayısıyla varyans- kovaryans matrislerinin homojenliği varsayımlarının karşılandı̆̆1 sonucuna ulaşılmıştır (Büyüköztürk, 2013, s. 21-23). Çok değişkenli normallik için Mahalonobis uzaklık değerleri hesaplanmış ve uç değerler analiz öncesinde veri setinden çıkarılmıştır. Bağımlı değişkenler arasındaki doğrusallık saçılım grafikleri ile incelenmiş ve ölçeklerin alt boyutlarına ilişkin doğrusallık varsayımının karşılandığı belirlenmiştir. Bu sonuçlardan hareketle, çok değişkenli normallik ve doğrusallığın sağlandığı, bağımlı değişkenler arasında çoklu bağlantı problemi olmadığı sonucuna ulaşılmıştır.

\section{Bulgular}

\section{Birinci Alt Probleme İlişkin Bulgular}

Araştırmanın birinci alt problemi olan “Okul öncesi eğitim kurumlarına devam eden çocukların ebeveynlerinin ebeveyn tutumları nelerdir?” sorusuna yönelik olarak ebeveynlerin ölçek maddelerine verdikleri yanıtlar üzerinden hesaplanan aritmetik ortalama ve standart sapma değerleri Tablo 2'de sunulmuştur.

Tablo 2. Okul Öncesi Eğitim Kurumlarna Devam Eden Cocuklarn Ebeveynlerinin Ebeveyn Tutumlarna İliskin Hesaplanan Ortalama ve Standart Sapma Değerleri

\begin{tabular}{lcc}
\hline Ölçek Alt Boyutları & $\bar{X}$ & ss \\
\hline Demokratik & 4.35 & 0.48 \\
Otoriter & 2.02 & 0.67 \\
Aşırı koruyucu & 4.02 & 0.67 \\
İzin verici & 2.25 & 0.65 \\
\hline
\end{tabular}

Tablo 2 incelendiğinde, okul öncesi eğitim kurumlarına devam eden çocukların ebeveynlerinin sırasıyla demokratik ( $\bar{X}=4.35)$ ve aşırı koruyucu $(\bar{X}=4.02)$ ebeveyn tutumlarını daha çok benimsedikleri, izin verici ( $\bar{X}=2.25)$ ve otoriter $(\bar{X}=2.02)$ ebeveyn tutumlarını ise daha az benimsedikleri görülmektedir.

\section{İkinci Alt Probleme İlişkin Bulgular}

Araştırmanın ikinci alt problemi olan "Okul öncesi eğitim kurumlarına devam eden çocukların ebeveynlerinin ebeveyn tutumları; a) çocuk sayısı, b) eğitim düzeyi, c) ailenin gelir düzeyi değişkenlerine göre anlamlı farklılık göstermekte midir?” sorusuna yönelik olarak yapılan analizlerden elde edilen bulgular aşağıda sırasıyla sunulmuştur.

Çocukların ebeveynlerinin ebeveyn tutum ölçeğinin alt boyutlarına ilişkin puanlarının çocuk sayısına göre anlamlı düzeyde farklılaşıp farklılaşmadığını belirlenmesi için MANOVA testi yapılmış ve sonuçlar Tablo 3'te sunulmuştur.

Tablo 3. Okul Öncesi Eğitim Kurumlarna Devam Eden Cocuklarm Ebeveynlerinin Ebeveyn Tutumlarmın Cocuk Sayısina Göre MANOVA Sonuçar

\begin{tabular}{llccc}
\hline Wilks' Lambda & F & Hipotez sd & Hata sd & P \\
\hline .911 & 4.076 & 12 & 1360 & .000 \\
\hline
\end{tabular}

Tablo 3'de görüldüğü üzere, okul öncesi eğitim kurumlarına devam eden çocukların ebeveynlerinin ebeveyn tutum ölçeğinin alt boyutlarından aldıkları puanlarda .05 anlamlılık düzeyinde çocuk sayısına göre anlamlı fark bulunmuştur (Wilks' Lambda .911, $\mathrm{F}_{(12,1360)}=4.076, \mathrm{p}<.05$ ). MANOVA testinde anlaml1 fark çıkması nedeniyle, çocuk sayısına göre grup ortalamalarının nasıl farklılaştığını inceleyebilmek amacıyla ANOVA testi yapılmış ve sonuçlar Tablo 4'de sunulmuştur. 
Tablo 4. Okul Öncesi Eğitim Kurumlarna Devam Eden Cocuklarn Ebeveynlerinin Ebeveyn Tutumlarmnn Cocuk Sayısina Göre ANOVA Sonuclar

\begin{tabular}{|c|c|c|c|c|c|c|c|c|c|c|c|}
\hline \multicolumn{5}{|c|}{ Betimsel Ístatistikler } & \multicolumn{7}{|c|}{ ANOVA Sonuçları } \\
\hline $\begin{array}{l}\text { Ölçek Alt } \\
\text { Boyutları }\end{array}$ & $\begin{array}{l}\text { Çocuk } \\
\text { say1s1 }\end{array}$ & $\boldsymbol{N}$ & $\bar{X}$ & ss & $\begin{array}{l}\text { Varyans } \\
\text { Kaynağı }\end{array}$ & $K . T$ & sd & $K . O$ & $F$ & $\boldsymbol{P}$ & $\begin{array}{c}\text { Anlamli } \\
\text { Fark }\end{array}$ \\
\hline \multirow{4}{*}{ Demokratik } & 1 & 55 & 4.52 & 0.35 & Gruplar arası & 7.768 & 3 & 2.589 & 12.021 & .000 & $1>4$ \\
\hline & 2 & 237 & 4.42 & 0.39 & Gruplar içi & 111.363 & 517 & 0.215 & & & $2>4$ \\
\hline & 3 & 133 & 4.35 & 0.47 & Toplam & 119.131 & 520 & & & & $3>4$ \\
\hline & 4 ve üzeri & 96 & 4.12 & 0.65 & & & & & & & \\
\hline \multirow{4}{*}{ Otoriter } & 1 & 55 & 1.90 & 0.53 & Gruplar arası & 3.713 & 3 & 1.238 & 2.813 & .039 & \\
\hline & 2 & 237 & 1.98 & 0.62 & Gruplar içi & 227.448 & 517 & 0.440 & & & \\
\hline & 3 & 133 & 2.05 & 0.70 & Toplam & 231.160 & 520 & & & & \\
\hline & 4 ve üzeri & 96 & 2.18 & 0.77 & & & & & & & \\
\hline \multirow{4}{*}{ Aşırı koruyucu } & 1 & 55 & 4.03 & 0.77 & Gruplar arası & 0.682 & 3 & 0.227 & 0.498 & .068 & \\
\hline & 2 & 237 & 3.98 & 0.66 & Gruplar içi & 236.064 & 517 & 0.457 & & & \\
\hline & 3 & 133 & 4.08 & 0.62 & Toplam & 236.746 & 520 & & & & \\
\hline & 4 ve üzeri & 96 & 4.01 & 0.73 & & & & & & & \\
\hline \multirow{4}{*}{ İzin verici } & 1 & 55 & 2.17 & 0.52 & Gruplar arası & 2.951 & 3 & 0.984 & 2.368 & .070 & \\
\hline & 2 & 237 & 2.28 & 0.62 & Gruplar içi & 214.803 & 517 & 0.415 & & & \\
\hline & 3 & 133 & 2.16 & 0.63 & Toplam & 217.754 & 520 & & & & \\
\hline & 4 ve üzeri & 96 & 2.37 & 0.78 & & & & & & & \\
\hline
\end{tabular}

Not: 1- " 1 çocuk" 2- "2 çocuk", 3- "3 çocuk ", 4-"4 ve üzeri çocuk"

Tablo 4 incelendiğinde, okul öncesi eğitim kurumlarına devam eden çocukların ebeveynlerinin ebeveyn tutumlarının çocuk sayısına göre farklılaştığı anlaşılmaktadır. Ayrıca, ebeveyn tutum ölçeğinin demokratik tutum alt boyutunda çocuk sayısına göre ortaya çıkan farkın anlamlı düzeyde olduğu görülmektedir $(\mathrm{p}<.0125)$. Çocuk sayısına göre farklılaşan ortalamaların hangi gruplardan kaynaklandığını belirlemek amacıyla yapılan çoklu karşılaştırma testlerinden Scheffe testi sonucunda; demokratik tutum boyutunda 4 ve üzeri çocuğu olan ebeveynler ile dörtten az çocuğu olan ebeveynler arasında dörtten az çocuğu olan ebeveynlerin lehine anlamlı farklılık olduğu belirlenmiştir.

Çocukların ebeveynlerinin ebeveyn tutum ölçeğinin alt boyutlanına ilişkin puanlarının ebeveyn eğitim düzeyine göre anlamlı düzeyde farklılaşıp farklılaşmadığını belirlenmesi için MANOVA testi yapılmış ve sonuçlar Tablo 5’te sunulmuştur.

Tablo 5. Okul Öncesi Eğitim Kurumlarna Devam Eden Cocuklarn Ebeveynlerinin Ebeveyn Tutumlarnmn Eğitim Düzeyine Göre MANOVA Sonuclar

\begin{tabular}{clccc}
\hline Wilks' Lambda & F & Hipotez sd & Hata sd & P \\
\hline .791 & 7.809 & 16 & 1567 & .000 \\
\hline
\end{tabular}

Tablo 5'te görüldüğü üzere, okul öncesi eğitim kurumlarına devam eden çocukların ebeveynlerinin ebeveyn tutum ölçeğinin alt boyutlarından aldıkları puanlarda .05 anlamlılık düzeyinde ebeveyn eğitim düzeyine göre anlamlı fark bulunmuştur (Wilks' Lambda .791, $\mathrm{F}_{(16,1567)}=7.809, \mathrm{p}<.05$ ). MANOVA testinde anlamlı fark çıkması nedeniyle, ebeveyn eğitim düzeyine göre grup ortalamalarının nasıl farklılaştığını inceleyebilmek amacıyla ANOVA testi yapılmış ve sonuçlar Tablo 6'da sunulmuştur. 
Tablo 6. Okul Öncesi Eğitim Kurumlarna Devam Eden Cocuklarn Ebeveynlerinin Ebeveyn Tutumlarmm Eğitim Düreyine Göre ANOV A Sonuclar

\begin{tabular}{|c|c|c|c|c|c|c|c|c|c|c|c|}
\hline \multicolumn{5}{|c|}{ Betimsel Ístatistikler } & \multicolumn{7}{|c|}{ ANOVA Sonuçları } \\
\hline $\begin{array}{l}\text { Ölçek Alt } \\
\text { Boyutları }\end{array}$ & $\begin{array}{l}\text { Ebeveyn eğitim } \\
\text { düzeyi }\end{array}$ & $\mathbf{N}$ & $\bar{X}$ & ss & $\begin{array}{l}\text { Varyans } \\
\text { Kaynağı }\end{array}$ & $K . T$ & $s d$ & K. $O$ & $F$ & $P$ & $\begin{array}{c}\text { Anlamli } \\
\text { Fark }\end{array}$ \\
\hline \multirow{5}{*}{ Demokratik } & Okur-yazar değil & 50 & 4.14 & 0.63 & Gruplar & 9.563 & 4 & 2.391 & 11.259 & .000 & $3>1,4>1$ \\
\hline & İlkokul & 171 & 4.27 & 0.53 & aras1 & 109.568 & 516 & 0.212 & & & $5>1,4>2$ \\
\hline & Ortaokul & 108 & 4.36 & 0.38 & Gruplar içi & 119.131 & 520 & & & & $5>2,5>3$ \\
\hline & Lise & 111 & 4.47 & 0.34 & Toplam & & & & & & \\
\hline & Üniversite & 81 & 4.56 & 0.32 & & & & & & & \\
\hline \multirow{5}{*}{ Otoriter } & Okur-yazar değil & 50 & 2.07 & 0.65 & Gruplar & 9.192 & 4 & 2.391 & 5.342 & .000 & $2>4$ \\
\hline & İlkokul & 171 & 2.18 & 0.76 & aras1 & 221.968 & 516 & 0.430 & & & $2>5$ \\
\hline & Ortaokul & 108 & 2.04 & 0.67 & Gruplar içi & 231.160 & 520 & & & & \\
\hline & Lise & 111 & 1.89 & 0.54 & Toplam & & & & & & \\
\hline & Üniversite & 81 & 1.83 & 0.53 & & & & & & & \\
\hline \multirow{5}{*}{ Aşırı koruyucu } & Okur-yazar değil & 50 & 4.03 & 0.70 & Gruplar & 13.084 & 4 & 3.271 & 7.547 & .000 & $1>5,2>5$ \\
\hline & İlkokul & 171 & 4.15 & 0.59 & aras1 & 223.661 & 516 & 0.433 & & & $3>5, \quad 4>5$ \\
\hline & Ortaokul & 108 & 4.10 & 0.66 & Gruplar içi & 236.746 & 520 & & & & \\
\hline & Lise & 111 & 4.00 & 0.62 & Toplam & & & & & & \\
\hline & Üniversite & 81 & 3.68 & 0.78 & & & & & & & \\
\hline \multirow{5}{*}{ İzin verici } & Okur-yazar değil & 50 & 2.17 & 0.57 & Gruplar & 21.925 & 4 & 0.481 & 7.547 & .332 & \\
\hline & İlkokul & 171 & 2.31 & 0.76 & aras1 & 215.829 & 516 & 0.418 & & & \\
\hline & Ortaokul & 108 & 2.21 & 0.60 & Gruplar içi & 217.754 & 520 & & & & \\
\hline & Lise & 111 & 2.21 & 0.65 & Toplam & & & & & & \\
\hline & Üniversite & 81 & 2.33 & 0.51 & & & & & & & \\
\hline
\end{tabular}

Tablo 6 verilerine göre, ebeveyn tutum ölçeğinin demokratik tutum, otoriter tutum ve aşırı koruyucu tutum boyutlarında ebeveyn eğitim düzeyine göre ortaya çıan farkın anlamlı düzeyde olduğu görülmektedir $(\mathrm{p}<.0125)$. Ebeveyn eğitim düzeyine göre farklılaşan ortalamaların hangi gruplardan kaynaklandığını belirlemek amacıyla yapılan çoklu karşılaştırma testlerinden Scheffe testi sonucunda; demokratik ebeveyn tutumu boyutunda ortaokul mezunu olan ebeveynler ile okur-yazar olmayan ebeveynler arasında ortaokul mezunu olan ebeveynler lehine anlamlı farklılık olduğu, lise mezunu ebeveynler ile okur-yazar olmayan ve ilkokul mezunu olan ebeveynler arasinda lise mezunu ebeveynler lehine anlamlı farklılık olduğu, üniversite mezunu ebeveynler ile okur-yazar olmayan, ilkokul ve ortaokul mezunu ebeveynler arasında üniversite mezunu olan ebeveynler lehine anlamlı bir farklılık olduğu görülmektedir. Bu durumda, demokratik ebeveyn tutumunda eğitim düzeyi yüksek olanlar lehine anlamlı farklılık çıktı̆̆1 görülmektedir. Otoriter ebeveyn tutumu boyutunda, ilkokul mezunu olan ebeveynler ile lise ve üniversite mezunu olan ebeveynler arasinda ilkokul mezunu olan ebeveynler lehine anlamlı farkllık olduğu belirlenmiştir. Așırı koruyucu ebeveyn tutumu boyutunda ise üniversite mezunu ebeveynler ile okur-yazar olmayan, ilkokul, ortaokul ve lise mezunu olan ebeveynler arasinda okur-yazar olmayan, ilkokul, ortaokul, lise mezunu olan ebeveynler lehine anlamlı farklılık olduğu ortaya çıkmıştır. Bu durumda, otoriter ve aşırı koruyucu ebeveyn tutumunda eğitim düzeyi düşük olanlar lehine anlamlı farklılık çıktı̆̆ görülmektedir.

Çocukların ebeveynlerinin ebeveyn tutum ölçeğinin alt boyutlarına ilişkin puanlarının aile gelir düzeyine göre anlamlı düzeyde farklılaşıp farklılaşmadığını belirlenmesi için MANOVA testi yapılmış ve sonuçlar Tablo 7'de sunulmuştur.

Tablo 7. Okul Öncesi Ë̈itim Kurumlarna Devam Eden Cocuklarm Ebeveynlerinin Ebeveyn Tutumlarmm Aile Gelir Düzeyine Göre MANOVA Sonuclar

\begin{tabular}{clccc}
\hline Wilks' Lambda & F & Hipotez sd & Hata sd & P \\
\hline .862 & 6.562 & 12 & 1360 & .000 \\
\hline
\end{tabular}

Tablo 7'de görüldüğü üzere, okul öncesi eğitim kurumlarına devam eden çocukların ebeveynlerinin ebeveyn tutum ölçeğinin alt boyutlarından aldıkları puanlarda .05 anlamlılık düzeyinde aile gelir düzeyine göre anlamlı fark bulunmuştur (Wilks' Lambda .862, $\mathrm{F}_{(12,1360)}=6.562, \mathrm{p}<.05$ ). MANOVA testinde anlamlı fark çıkması nedeniyle, aile gelir düzeyine göre grup ortalamalarının nasıl farklılaştığını inceleyebilmek amacıyla ANOVA testi yapılmış ve sonuçlar Tablo 8'de sunulmuştur. 
Tablo 8. Okul Öncesi Eğitim Kurumlarna Devam Eden Cocuklarn Ebeveynlerinin Ebeveyn Tutumlarmm Aile Gelir Düreyine Göre ANOVA Sonuclar

\begin{tabular}{|c|c|c|c|c|c|c|c|c|c|c|c|}
\hline \multicolumn{5}{|c|}{ Betimsel Ístatistikler } & \multicolumn{7}{|c|}{ ANOVA Sonuçlatı } \\
\hline $\begin{array}{l}\text { Ölçek Alt } \\
\text { Boyutlanı }\end{array}$ & $\begin{array}{l}\text { Aile Gelir } \\
\text { düzeyi }\end{array}$ & $\boldsymbol{N}$ & $\bar{X}$ & ss & $\begin{array}{l}\text { Varyans } \\
\text { Kaynağ1 }\end{array}$ & $K . T$ & $s d$ & K.O & $F$ & $\boldsymbol{P}$ & $\begin{array}{c}\text { Anlamli } \\
\text { Fark }\end{array}$ \\
\hline \multirow{4}{*}{ Demokratik } & $0-1499$ & 181 & 4.21 & 0.59 & Gruplar aras1 & 6.447 & 3 & 2.149 & 9.859 & .000 & $2>1$ \\
\hline & $1500-2499$ & 149 & 4.41 & 0.40 & Gruplar içi & 112.684 & 517 & 0.218 & & & $4>1$ \\
\hline & $2500-3499$ & 82 & 4.37 & 0.42 & Toplam & 119.131 & 520 & & & & \\
\hline & 3500 ve üzeri & 109 & 4.50 & 0.35 & & & & & & & \\
\hline \multirow{4}{*}{ Otoriter } & $0-1499$ & 181 & 2.16 & 0.75 & Gruplar aras1 & 7.484 & 3 & 2.495 & 5.766 & .001 & $1>3$ \\
\hline & $1500-2499$ & 149 & 2.05 & 0.68 & Gruplar içi & 223.676 & 517 & 0.433 & & & $1>4$ \\
\hline & 2500-3499 & 82 & 1.90 & 0.56 & Toplam & 231.160 & 520 & & & & \\
\hline & 3500 ve üzeri & 109 & 1.86 & 0.52 & & & & & & & \\
\hline \multirow{4}{*}{ Aşırı koruyucu } & $0-1499$ & 181 & 4.06 & 0.67 & Gruplar arası & 9.876 & 3 & 3.292 & 7.502 & .000 & $1>4$ \\
\hline & $1500-2499$ & 149 & 4.17 & 0.59 & Gruplar içi & 226.870 & 517 & 0.439 & & & $2>4$ \\
\hline & 2500-3499 & 82 & 3.97 & 0.72 & Toplam & 236.746 & 520 & & & & \\
\hline & 3500 ve üzeri & 109 & 3.78 & 0.69 & & & & & & & \\
\hline \multirow{4}{*}{ İzin verici } & $0-1499$ & 181 & 2.24 & 0.73 & Gruplar aras1 & 0.353 & 3 & 0.118 & 0.280 & .840 & \\
\hline & $1500-2499$ & 149 & 2.30 & 0.64 & Gruplar içi & 217.401 & 517 & 0.421 & & & \\
\hline & 2500-3499 & 82 & 2.23 & 0.53 & Toplam & 217.754 & 520 & & & & \\
\hline & 3500 ve üzeri & 109 & 2.25 & 0.59 & & & & & & & \\
\hline
\end{tabular}

Not: 1- " 0-1499", 2- "1500-2499", 3- "2500-3499", 4-"3500 ve üzeri"

Tablo 8 incelendiğinde, okul öncesi eğitim kurumlarına devam eden çocukların ebeveynlerinin ebeveyn tutumlarının aile gelir düzeyine göre farklılaştığı anlaşılmaktadır. Tablo 8 verilerine göre, ebeveyn tutum ölçeğinin demokratik, otoriter ve aşırı koruyucu alt boyutlarında aile gelir düzeyine göre ortaya çıan farkın anlamlı düzeyde olduğu görülmektedir $(\mathrm{p}<.0125)$. Aile gelir düzeyine göre farklılaşan ortalamaların hangi gruplardan kaynaklandığını belirlemek amacıyla yapılan çoklu karşılaştırma testlerinden Scheffe testi sonucunda; demokratik ebeveyn tutumu alt boyutunda ailenin gelir düzeyi "0-1499 TL" arasi olan ebeveynler ile gelir düzeyi daha yüksek olan ebeveynler arasında gelir düzeyi yüksek (1499 TL'nin üzerinde) olan ebeveynler lehine anlamlı farklılık olduğu belirlenmiştir. Bu durumda, demokratik ebeveyn tutumunda aile gelir düzeyi yüksek olanlar lehine anlamlı farklılık çıktığı görülmektedir. Otoriter ebeveyn tutumu alt boyutunda ailenin gelir düzeyi "0-1499 TL" arası olan ebeveynler ile gelir düzeyi daha yüksek olan (2500 TL'nin üzerinde) ebeveynler arasında gelir düzeyi "0-1499 TL" arası olan ebeveynler lehine anlamlı farklilik olduğu belirlenmiştir. Aşırı koruyucu ebeveyn tutumu alt boyutunda ise ailenin gelir düzeyi "3.500 TL ve üzeri" arası olan ebeveynler ile gelir düzeyi daha düşük olan (2499 TL'nin altında) ebeveynler arasında gelir düzeyi düşük olan ebeveynler lehine anlamlı farkllık olduğu belirlenmiştir. Bu durumda, otoriter ve aşırı koruyucu ebeveyn tutumunda aile gelir düzeyi düşük olanlar lehine anlamlı farklılık çıktığ1 görülmektedir.

\section{Tartışma, Sonuç ve Öneriler}

Araştırmada, okul öncesi eğitim kurumlarına devam eden çocukların ebeveynlerinin en fazla demokratik tutum sergiledikleri bunun yanı sıra aşırı koruyucu tutum alt boyutunda da yüksek ortalamaya sahip oldukları sonucuna ulaşılmıştır. Ayrıca, ebeveynlerin otoriter ve izin verici tutumu daha az sergiledikleri belirlenmiştir. Alanyazında bu araştırma sonuçlarıyla benzer ve farklı sonuçlara ulaşan çalışmalar bulunmaktadır. Bu araştırma sonuçlarıyla paralel olarak, Güner (2011) yaptıkları çalışmada, ebeveynlerin en fazla demokratik ve aşırı koruyucu tutumu benimsediklerini belirlemişlerdir. Özyürek ve Şahin (2005) yaptıkları çalışmada, ebeveynlerin sırasıyla demokratik-eşitlik, aşırı koruyucu, sert disiplin tutumlarını benimsediklerini ortaya koymuştur. Benzer şekilde, Çetinkaya (2016) sadece annelerin tutumunu incelediği çalışmasında, annelerin en fazla demokratik tutumu benimsediklerini ortaya koymuştur. Yalçın (2014) yaptı̆̆ çalışmada, ebeveynlerin demokratik ve aşırı koruyucu tutuma yüksek düzeyde sahip oldukları, otoriter tutuma ise düşük düzeyde sahip oldukları sonucuna ulaşmışır. Garip (2010) çalışmasında, ebeveynlerin daha çok demokratik tutumu benimsediklerini belirlemiştir. Çetinel (2016) annenin çocuk yetiştirme tutumu ile çocuğun dinleme becerisini inceledikleri çalışmada, annelerin çoğunluğunun demokratik tutum sergilediklerini belirlemişlerdir. Bu araştırmalardan farklı olarak, TaşZalluhoğlu (2015) yaptığ çalışmada, psikiyatri kliniğine gitmiş çocukların annelerinin en fazla otoriter tutumu en az ise demokratik tutumu benimsediklerini ortaya koymuştur. Benzer şekilde, Andı (2014) çalısmasında ebeveynlerin en fazla sıkı disiplinli tutuma, en az ise demokratik tutuma sahip olduklarını belirlemişlerdir. Aktürk (2015) yaptığ1 çalışmada, ebeveynlerin en çok otoriter tutumu, en az ise aşırı koruyucu tutumu sergilediklerini belirlemiştir. Berg (2011) 14 ebeveynle yaptığ1 çalsşmada, 10 ebeveynin 
yetkili tutuma, üç ebeveynin otoriter tutuma ve bir ebeveynin ise izin verici tutuma sahip olduğu sonucuna ulaşmıştır.

Alanyazındaki benzer çalışma sonuçları ve bu araştırmada ulaşılan sonuçlar, ebeveynlerin sıklıkla demokratik ve aşırı koruyucu tutum sergilediklerini göstermektedir. En başarılı ve sağlıklı bir tutum olan demokratik tutumda ebeveyn çocuğun duygu, düşünce ve kararlarına değer verir, çocukla iletişime dayalı bir ilişki kurar ve çocuğun gelişimsel ihtiyaçlarını önemser (Çağdaş ve Seçer, 2011; Yavuzer, 2003, s. 2630). Demokratik tutumla yetişen çocuklar olumlu benlik algısına sahip, özgüveni yüksek, kendi kararlarını ve sorumluluğunu alabilen bireyler olurlar (Durmuş, 2006, s. 38-39; Maccoby ve Martin, 1983, s. 38-39). Aşırı koruyucu tutumda ise ebeveyn aşırı sevgi ve denetimden dolayı çocuğun bireysel ve bağımsız gelişmesine engel olmaktadır (Çağdaş ve Seçer, 2011; Yavuzer, 2003, s. 26-30). Araştırma sonuçları değerlendirildiğinde, ebeveynlerin daha çok demokratik tutum sergiledikleri, çocuklarının fikirlerini, hak ve sorumluklarını dikkate aldıkları söylenebilir. Dolayısıyla, bu sonuç çocuğun sosyal yeterliliğe sahip, öz güveni yüksek, empati kurabilen bir birey olabilmesi açısından olumlu olarak değerlendirilebilir. Bunun yanı sıra, aşırı koruyucu tutumun da yüksek çıkması çocukların bağımsız düşünebilen ve karar verebilen birey olmasını engelleyeceği için bu sonucun olumsuz olduğu söylenebilir. Ayrıca, ebeveynlerin daha çok demokratik tutum sergilemelerinin yanı sıra aşırı koruyucu tutumu da sıklıkla sergilemeleri onların çocuklarına gereğinden fazla kontrol ve özen göstererek iyi bir ebeveyn olduklarını düşündükleri, fakat gerçekte çocuklarının psiko-sosyal gelişimini olumsuz etkiledikleri söylenebilir.

Araştırmada, ebeveynlerin ebeveyn tutumlarının çocuk sayısına göre anlamlı düzeyde farklılaştığı sonucuna ulaşılmıştır. Bir başka deyişle, tek çocuğa sahip ebeveynlerin iki ve daha fazla çocuğa sahip ebeveynlere oranla demokratik tutumu daha fazla benimsedikleri belirlenmiştir. Bu çalişma sonuçlarıyla benzer ve farklı sonuçlar elde eden çalışmalar bulunmaktadır. Bu araştırma sonuçlarına paralel olarak, Özyürek ve Şahin (2005) yaptıkları çalışmada, çocuk sayısı arttıkça otoriter tutumun arttığ1, demokratik tutumun azaldığını belirlemişlerdir. Garip (2010) yaptığı araştırmada, çocuk sayısı ile demokratik tutumun paralellik gösterdiği, üç ve daha fazla çocuklu ailelerin otoriter tutum puanlarının daha yüksek olduğunu belirlemiştir. Sak ve diğerleri (2015) yaptıkları çalışmada, iki çocuğa sahip ebeveynlerin demokratik tutumlarının dört ve üzeri çocuğa sahip ebeveynlerden daha yüksek olduğunu, otoriter tutumda ise dört ve üzeri çocuğa sahip ebeveynlerin ortalamalarının daha yüksek olduğunu belirlemişlerdir. Bu araştırma sonuçlarından farklı olarak, Aktürk (2015) yaptı̆̆ı çalışmada, çocuk sayısı arttıkça demokratik tutumun arttı̆̆1, otoriter tutumun ise azaldığı sonucuna ulaşmıştır. Alayazındaki benzer çalışma sonuçları ve bu çalışmadan elde edilen sonuçlar değerlendirildiğinde, çocuk sayısı arttıkça demokratik tutumun azaldığı görülmektedir. Bu araştırma sonuçlarından hareketle tek çocuğa sahip ebeveynlerin çocuğa daha fazla vakit ayırmaları, aile içinde alınacak kararlarda çocuğa daha fazla söz hakkı vermeleri, çocuğun duygu ve düşüncelerini daha fazla önemsemelerinden dolayı ebeveynlerin demokratik tutumu daha fazla benimsedikleri söylenebilir.

Araştırmada, ebeveynlerin eğitim düzeyine göre ebeveyn tutumlarının anlamlı düzeyde farklılaştığ1 sonucuna ulaşılmıştır. Ebeveynlerin eğitim düzeyi yükseldikçe demokratik tutumu daha fazla benimsedikleri, otoriter ve aşırı koruyucu tutumu ise daha az benimsedikleri belirlenmiştir. Alanyazında bu araştırma sonuçlarıyla benzer ve farklı sonuçlar elde eden çalışmalar bulunmaktadır. Bu araştırma sonuçlarına paralel olarak, Özyürek ve Şahin (2005) yaptıkları çalışmada, aşırı koruyucu tutumda en düşük ortalamaya üniversite mezunu annelerin sahip olduğu sonucuna ulaşmışlardır. Aktürk (2015) yaptığ1 çalışmada, ilkokul mezunu annelerin diğer eğitim düzeyindeki annelere göre izin verici tutumu daha fazla sergilediklerini, buna karşın aşırı koruyucu tutumu daha az sergilediklerini belirlemiştir. Bazarbaşı (2004) annelerin çocuk yetiştirme tutumlarını incelediği çalışmasında, ilkokul mezunu annelerin izin verici tutumunun diğer eğitim düzeyindeki annelere göre daha yüksek olduğu sonucuna ulaşmıştır. Durmuş (2006) yaptığ1 çalışmada, ilkokul mezunu annelerin aşırı koruyucu ve otoriter tutumlarını daha fazla benimsediklerini belirlemiştir. Öztürk ve Şanlı (2007) yaptıkları çalışmada, ilkokul mezunu annelerin aşırı koruyucu tutumu diğer eğitim düzeyindeki annelerden daha çok benimsediklerini ortaya koymuştur. Sar1 (2007) çalışmasında, annelerin eğitim seviyesi düştükçe aşırı koruyucu tutumlarının arttığını belirlemiştir. Çetinkaya (2016) yaptıkları çalışmada, demokratik tutum boyutunda en yüksek ortalamaya üniversite mezunu annelerin sahip olduğu, otoriter tutum boyutunda ise en yüksek ortalamaya ilkokul mezunu annelerin sahip olduğu sonucuna ulaşmıslardır. Benzer şekilde, Ucur (2005) çalışmasında lise ve altı eğitim düzeyindeki annelerin üniversite mezunu annelerden daha fazla koruyucu, kontrollü, sıkı disipline önem verdiklerini belirlemiştir. Bu araştırma sonuçlarından farklı olarak, Andı (2014) yaptığı çalışmada, ilköğretim mezunu annelerin üniversite mezunu annelerden daha demokratik tutum sergilediklerini, 
üniversite mezunu annelerin ilköğretim mezunu annelerden daha az koruyucu tutum sergilediklerini belirlemiştir. Karabulut Demir ve Şendil (2008) ebeveyn tutum ölçeğini geliştirdikleri çalışmada, annelerin eğitim düzeyi ile birlikte demokratik, otoriter ve aşırı koruyucu tutumlarının arttığını ortaya koymuşlardır. Alanyazındaki benzer çalışma sonuçları ve bu çalışmadan elde edilen sonuçlar değerlendirildiğinde, ebeveynlerin eğitim düzeyi yükseldikçe demokratik tutumu daha fazla benimsedikleri, otoriter ve aşır1 koruyucu tutumu ise daha az benimsedikleri söylenebilir. Ebeveynin eğitim düzeyi yükseldikçe ebeveynler çocuk yetiştirmede yeni fikir ve uygulamaları daha kolay kabul ederek geleneksel tutumdan uzaklaşırlar (Özyürek ve Şahin, 2005, s. 31; Ucur, 2005, s. 120-121). Bu araştırma sonuçlarından hareketle, ebeveynin eğitim düzeyi yükseldikçe çocuk gelişimiyle ilgili bilgilerinin, çocukların hak ve sorumluklarıyla ilgili bilinçlerinin arttığı, empati kurma ve iletişim becerilerinin geliştiği böylece çocuklarına aile içinde daha fazla söz hakkı verdikleri söylenebilir. Ayrıca, ebeveynlerin eğitim düzeyi yükseldikçe çocukları üzerinde aşırı baskı ve disiplin kurma, gereğinden fazla kontrol ve özen gösterme gibi davranışlarının azaldığını söylemek mümkündür.

Araştırmada, ebeveynlerin gelir düzeyine göre ebeveyn tutumlarının anlamlı düzeyde farklılaştı̆̆ sonucuna ulaşılmıştır. Gelir düzeyi yüksek olan ebeveynlerin demokratik tutumu daha fazla, aşırı koruyucu tutumu ise daha az benimsedikleri, düşük gelirli ailelerin otoriter ve aşırı koruyucu tutumu daha fazla benimsedikleri belirlenmiştir. Alanyazında bu araştırma sonuçlarıyla benzer ve farklı sonuçlara ulaşan çalışmalar bulunmaktadır. Bu araştırma sonuçlarına paralel olarak, Çetinkaya (2016) yaptıkları çalışmada, gelir düzeyi düşük olan ebeveynlerin aşırı koruyucu tutumu daha çok benimsediklerini belirlemişlerdir. Yener (2014) yaptı̆̆ı çalışmada, geliri düşük olan ebeveynlerin demokratik tutum boyutu hariç diğer boyutlarda en yüksek ortalamaya sahip olduklarını belirlemiştir. Garip (2010) yaptığı çalışmada, geliri düşük olan ebeveynlerin otoriter tutumu daha fazla benimsediklerini belirlemiştir. Balat (2007) yaptı̆ğ çalışmada, üst sosyo-ekonomik düzeydeki ebeveynlerin demokratik ve eşitlik tutumlarını diğer sosyo-ekonomik düzeydeki ebeveynlerden daha fazla benimsediklerini ortaya koymuştur. Bu sonuçlardan farklı olarak, Andı (2014) çalışmalarında, gelir düzeyi yüksek olan ebeveynlerin otoriter tutumu daha fazla benimsediklerini belirlemişlerdir. Alanyazındaki benzer çalışma sonuçları ve bu araştırma sonuçları değerlendirildiğinde, genel olarak yüksek gelire sahip ebeveynlerin çocuklarına karşı daha olumlu tutum sergiledikleri ve daha demokratik davrandıkları, gelir düzeyi düşük ebeveynlerin ise çocuklarına karşı daha kontrolcü ve baskıcı bir tutum sergiledikleri söylenebilir. Yavuzer'e (2011) göre ebeveynlerin doğru tutumu sergileyebilmesi için aile içinde barışık, dengeli ve huzur içinde olmaları gerekmektedir. Dolayısıyla, yüksek gelirli ebeveynlerin çocuğun bakımı ve gelişimiyle daha yakından ilgilendiği, çocuğun duygu ve düşüncelerini önemsediği ve daha doğru tutum sergiledikleri söylenebilir. Buna karşın düşük gelirli ailelerde geçim sıkıntısından dolayı ebeveynlerin gergin ve stresli oldukları, yeterli eğitim ve imkânlara sahip olamadıkları, çocuklarıla daha az vakit geçirdikleri ve bu nedenle çocuğun eğitiminde daha fazla otoriter ve koruyucu tutum benimsedikleri düşünülmektedir.

Araştırmadan elde edilen sonuçlar doğrultusunda aşağıdaki öneriler sunulmuştur:

a) Araştırma sonuçlarına göre ebeveynler en fazla demokratik tutumu ve aşırı koruyucu tutumu benimsemektedir. Ebeveynlerin doğru tutumu benimseyebilmeleri için çocuk yetiştirme tutumları ile ilgili seminer, kurs, anne-baba eğitim programlarının hazırlanması önerilebilir. Ayrıca, bu eğitimler sayesinde çocuğun iyiliği için yaptı̆̆ını düşünen fakat farkında olmadan bağımlı ve özgüveni düşük birey yetiştiren aşırı koruyucu tutum sergileyen ebeveynlerin doğru tutum olan demokratik tutumu benimsemeleri sağlanabilir.

b) Ebeveyn tutumlarının çocuğun diğer gelişim alanları ile ilişkinin incelendiği çalışmalar yapılabilir.

c) Bu araştırma, nicel veri toplama araçlarıyla ve Van ilinde öğrenim gören çocukların ebeveynleriyle sınırlıdır. Farklı bölgelerde öğrenim gören çocukların ebeveynleriyle çalışmalar yapılabilir ve ebeveynlerin tutumlarılla ilgili görüşmeler yapılarak veri çeşitliliği sağlanabilir.

\section{Etik Beyan}

"Cocuklar Okul Öncesi Ë̆itim Kurumlarna Devam Eden Ebeveynlerin Tutumlarnnn Incelenmesi" başlıklı çalışmanın yazım sürecinde bilimsel, etik ve alıntı kurallarına uyulmuş; toplanan veriler üzerinde herhangi bir tahrifat yapılmamış ve bu çalışma herhangi başka bir akademik yayın ortamına değerlendirme için gönderilmemiştir. 


\section{Kaynakça}

Aktürk, M. F. (2015). Cocuklar okul öncesi eğitime devam eden (5 yaş grubu) ebeveynlerin ana-baba tutumlarmm farkh değişkenler açsından incelenmesi (Yüksek Lisans Tezi). Selçuk Üniversitesi, Sosyal Bilimler Enstitüsü, Konya.

Altay, F. B. ve Güre, A. (2012). Okul öncesi kuruma (devlet-özel) devam eden çocukların sosyal yeterlik ve olumlu sosyal davranışları ile annelerinin ebeveynlik stilleri arasındaki ilişkiler. Kuram ve Uygulamada Eğitim Bilimleri, 12(4), 2699-2718.

Andı, F. T. (2014). Okul öncesi çocuklarda ögretmen tarafindan ölçülen sosyal davranıs denetimi, sosyal uyum ve sosyal yeterlilik düzeylerinin, ebeveyn çocuk yetiştirme tutumlar ile ilişkisinin incelenmesi (Yüksek Lisans Tezi). Haliç Üniversitesi, Sosyal Bilimler Enstitüsü, İstanbul.

Aypay, A., Çekiç, O., ve Seçkin, M. (2012). Öğretim elemanlarının öğretime ilişkin görüşlerinin normatif açısından incelenmesi. Kuram ve Uygulama Eğitim Bilimleri, 12(2), 1345-1366.

Balat, G. U. (2010). İlköğretime başlayan çocukların anne babalarının çocuk yetiştirme tutumlarının okul öncesi eğitimden yararlanma düzeylerine göre incelenmesi. Ë̆itim ve Bilim, 32(143).

Bazarbaşı, F. (2014) 2-6 yaşlarda çocuklar olan annelerin duygusal zeka düzeyleri ve bazı demografik özellikleri ile çocuk yetiştirmeye yönelik tutumlar arasindaki ilişkinin incelenmesi (Yüksek Lisans Tezi). Çukurova Üniversitesi, Sosyal Bilimler Enstitüsü, Adana.

Berg, B. (2011). The effects of parenting styles on a preschool aged Child's social emotional development. The Graduate School University of Wisconsin.

Büyüköztürk, Ş. (2013). Sosyal bilimler için veri analiz̧i el kitabı. Ankara: Pegem Akademi.

Büyüköztürk, S., Çakmak, E., Akgün, Ö. E., Karadeniz, S., ve Demirel, F. (2012). Bilimsel araştırma yöntemleri (13. Baskı). Ankara: Pegem Akademi Yayıncılık.

Çağdaş, A. ve Seçer, Z. (2011). Anne baba eğitimi. Ankara: Eğiten Kitap.

Çetinel, G. (2016). Okul öncesi dönem çocuğuna sabip annelerin çocuk yetistirme tutumu ile çocuğun dinleme becerisi arasindaki iliskinin incelenmesi (Yüksek Lisans Tezi). Çă̆ Üniversitesi. Mersin.

Çetinkaya, N. (2016). 4-5 yas arası okul öncesi çocuklarm sosyal duygusal uyumu ile anne-babalarn çocuk yetiştirme tutumlar arasindaki ilişki (Yüksek Lisans Tezi). Kafkas Üniversitesi, Sosyal Bilimler Enstitüsü, Kars.

Durmuş, R. (2006). 3-6 yaş arası çocuğu olan ebeveynlerin kişilik özellikleri ile anne-baba tutumlarnnn baz̨ değişkenlere göre incelenmesi (Yüksek Lisans Tezi). Marmara Üniversitesi, Eğitim Bilimleri Enstitüsü, İstanbul.

Erkan, S. (2013). Aile ve aile eğitimi ile ilgili temel kavramlar (Edt: Z. Fulya Temel). Aile eğitimi ve erken çocukluk eğitiminde aile katılım çalışmalar. Ankara: Anı Yayıncılık.

Fraenkel, J. R., Wallen, N. E. ve Hyun, H. H. (2012). How to design and evaluate research in education. USA: The McGrawHill Companies, Inc.

Garip, S. (2010). 5-6 yaş döneminde, okul öncesi eğitim kurumuna devam eden çocuğu olan eşlerin çocuk yetiştirme stilleri ile evlilik uyumlar arasindaki ilişkinin incelenmesi (Yüksek Lisans Tezi). Marmara Üniversitesi, Eğitim Bilimleri Enstitüsü, Ankara.

Güner, A. (2011). Okul öncesi çocuklar ve ebeveynlerinin bağlanma güvenlikleri ile çocuk yetistirme tutumlar arasindaki ilişkilerin incelenmesi (Yüksek Lisans Tezi). İstanbul Üniversitesi, Sosyal Bilimler Enstitüsü, İstanbul.

Karabulut Demir, E. ve Şendil, G. (2008). Ebeveyn tutum ölçeği (ETÖ). Türk Psikoloji Yazılar, 11(21), 15-25.

Karasar, N. (2015). Araştırmalarda rapor hą̧rlama (19. Baskı). Ankara: Nobel Akademik Yayınc1lık.

Maccoby, E. ve Martın, J. A. (1983). Socialization in the context of family: Parent-child interaction. Handbook of child psychology: Vol. 4. Socialization, personality, and social development (Edt: E. M. Hetherington, P. H. Mussen). New York: Wiley. pp. 1-101.

Miller, R. G. Jr. (1991). Simultaneous statistical inference. New York: Springer Verlog.

Mussen, P. H., Conger, J. J., Kagan, J. ve Huston, A. C. (1984). Child development and personality. New York: Harper \& Row, Publishers.

Özbey, S. (2010). Okul öncesi çocuklarda uyum ve davranış problemleriyle başa çıkmada ailenin rolü. Aile ve Toplum Dergisi, 6(22).

Özgün, Ö. (2013). Ebeveynlikle ilgili kuramlar ve araştırmalar. Temel, F. Z.(Ed.). Aile eğitimi ve erken çocukluk eğitiminde aile katılım çalışmalar. Ankara: Anı Yayıncilık.

Özkafac1, A. (2012). Annenin çocuk yetistirme tutumu ile çocuğun sosyal beceri düzeyi arasındaki ilişkinin incelenmesi (Yüksek lisans tęi). İstanbul Arel Üniversitesi, Sosyal Bilimler Enstitüsü.

Öztürk, C. ve Şanlı, D. (2007). Annelerin eğitim durumunun çocuk yetiştirme tutumlarına etkisinin incelenmesi. Ege Pediatri Bülteni, 14(3), 145-150.

Özyürek, A. ve Şahin, F. T. (2005). 5 ve 6 Yaş grubunda çocuğu olan ebeveynlerin tutumlarının incelenmesi. Gą̧i Üniversitesi Gazi Eğitim Fakültesi Dergisi, 25(2).

Özyürek, A. ve Tezel Şahin, F. (2010). Anne-baba olmake ve anne-babalarn çocuk yetiștirme tutumlar. Anne baba eğitimi (Ed: T. Güler), 35-52, Ankara: Pegem Akademi Yayınc1lık.

Padem, H., Göksu, A. ve Konaklı, Z. (2012). Arasttrma yöntemleri (SPSS uygulamal). Saraybosna: IBU Publications.

Pallant, J. (2005). SPSS survival manual: A step by step guide to data analysis using SPSS for windows. Australia: Australian Copyright.

Rubin, K. H, Bukowski, W. ve Parker, J. (2006). Peer interactions, relationships, and groups. Handbook of Child Psychology: Social, Emotional, and Personality Development (p.571-645). USA: New York. 
Sak, R., Şahin Sak, İ. T., Atlı, S. ve Şahin, B. K. (2015). Okul öncesi dönem: Anne- baba tutumlar1. Mersin Üniversitesi Ë̆itim Fakültesi Dergisi, 11(3), 972- 991.

Santrock, J. W (1997). Life span development. London, Brown Benchmark Publishers.

Sar1, E. (2007). Anasinrfina devam eden 5-6 yas grubu çocuklarm, annelerinin çocuk yetiştirme tutumlarmm, çocuğun sosyal uyum ve becerilerine etkisinin incelenmesi (Yüksek Lisans Tezi). Gazi Üniversitesi, Eğitim Bilimleri Enstitüsü, Ankara.

Taş-Zalluhoğlu, B. (2015). 4-6 yas aralığındaki okul öncesi çocuklarn ve annelerinin bağlanma örüntüleri ile annelerinin ebeveyn tutumlar ve stresle başa çıkma yaklaşımlarmm incelenmesi: çocuk psikiyatri kliniğine başvuran ve başvurmamıs olan çocuklarm karşılaştırlması (Yüksek Lisans Tezi). Hacettepe Üniversitesi, Sosyal Bilimler Enstitüsü, Ankara.

Tezel-Şahin, F. ve Cevher F. N. (2007). Türk toplumunda aile-çocuk ilişkilerine genel bir bakış. ICANAS 38. Ankara.

Ucur, Z. E. (2005). Farkl aile tutumlarmm okulöncesi dönem 5 yaş çocuklarmm bilissel performans düreylerine etkisi (Yüksek Lisans Tezi). Maltepe Üniversitesi, Sosyal Bilimler Enstitüsü, İstanbul.

Ünal, S. (2007). Atılganlı becerileri eğitim programmm ilkögretim ikinci kademe ögrrencilerinin atılganlık düzeyi ve benlik saygısı üzerindeki etkisi (Yüksek Lisans Tezi). Dokuz Eylül Üniversitesi, Eğitim Bilimleri Enstitüsü, İzmir.

Yalçın, V. (2014). Okul öncesi dönem çocuklarmm okula uyum süreci ile ebeveynlerinin çocuk yetiştirme tutumlar arasındaki ilişki (Yüksek Lisans Tezi). Anadolu Üniversitesi, Eğitim Bilimleri Enstitüsü, Eskişehir.

Yavuzer, H. (2003). Cocuğu tanmak ve anlamak (2. baski). İstanbul: Remzi Kitabevi.

Yavuzer, H. (2011). Anne baba ve çocuk. İstanbul: Remzi Kitapevi.

Yavuzer, H. ve Demir, İ. (2016). Yeni kuşak anne-babalar ve çocuklar. İstanbul, Remzi Kitapevi.

Yener, P. (2014). Okul öncesi eğitimi alan 60 ay ve üzeri çocuklarn sosyal beceri düzeyleri ile annelerinin çocuk yetiştirme tutumlar arasindaki iliskinin incelenmesi (Yüksek Lisans Tezi). Gazi Üniversitesi, Eğitim Bilimleri Enstitüsü, Ankara.

Yörükoğlu A. (1987). Çocuk ruh sağlı̆̆. Türkiye İş Bankası Kültür Yayınları, Ankara.

\section{EXTENDED ABSTRACT}

The anthropologists first examined the relationship between mother, father and child. Anthropologists examined how the parent interacts with the child, cares for the child, the role distribution among the family and how the parent transfers his/her interest, experience and culture to his/her children. Later psychological studies investigated the effects of parental attitudes and behaviors on child development. Especially the communication between mothers and children who assume more responsibility in the development of the child has been examined and it has been determined that the personality and mental problems of the child are caused by the attitudes and behaviors of mothers (Özgün, 2013, p.73-76). In the meantime, the studies on this subject still maintain their importance as father's attitudes as well as maternal attitudes may have a decisive influence on the child.

In the literature, parental attitudes are grouped in different ways. In this study, parental attitudes are discussed in four dimensions as democratic attitude, authoritarian attitude, over- protective attitude and permissive attitude. In a democratic parental attitude, parents support children's independence in a controlled manner. In the authoritarian parental attitude, parents are not sensitive to the wishes of children. Parents with over-protective attitudes try to protect their children from dangers and keep them under control to limit their children's development. Parents adopting permissive parental attitudes try to fulfill what the child says and is managed by his/her children. Therefore, it is important to determine parental attitudes of parents who have children studying in preschool education institutions, which is known as the first stage of the education process. The aim of this study is to determine parental attitudes of parents whose children attend preschool education institutions affiliated to the Ministry of National Education in the 2017-2018 academic year.

Parental attitudes have a significant impact on the child's recognition of himself and the society in which he lives, to live in harmony and to complete his social development in a healthy way. The social developments have changed the parental attitudes that shape the child's present and future life. Although parental attitudes change, the importance of child development continues (Erkan, 2013, p.10). Therefore, it is necessary to determine parental attitudes in order to increase the quality of childhood which is of vital importance. Therefore, this study is important in terms of determining parental attitudes of parents of children attending preschool education institutions. In addition, it is thought that this study will contribute to the related literature by showing whether the parental attitudes of parents differ according to variables such as number of children, parental education level and family income level.

In this study, descriptive survey model was used. The target population of the study comprise the parents of 12,183 children who are attending preschool education institutions affiliated to the Ministry of National Education in the central districts of Van province that are Ipekyolu, Tuşba and Edremit in the 2017-2018 academic year. The sample of the study consists of 521 parents that were determined by stratified sampling method. In this study, "Parental Attitude Scale" was used to identify parents' parental 
attitudes. In the analysis of research data, descriptive statistics (mean, standard deviation) and differential statistics (ANOVA, MANOVA) were used.

As a result of study, it was concluded that the parents of the children exhibit democratic and overprotective parental attitudes at most, respectively. They exhibit permissive and authoritarian attitudes at least, respectively. As the number of children increases, the democratic attitude decreases; as the parents' level of education and income increase, the parents adopt the democratic attitude more, but the authoritarian and over-protective attitude are adopted less. Based on the results of the research, the following suggestions are presented:

a) As a result of the research, it was found that parents of the children exhibit democratic and overprotective parental attitudes at most, respectively. In order for parents to adopt the right attitude, it is advisable to prepare seminars, courses and parent education programs on child growing attitudes. In addition, through these trainings, parents who adopt an overprotective attitude who think that they are doing for the sake of the child, but who are not aware of it, can be provided with the right attitude to adopt the democratic attitude.

b) Studies on the relationship between parental attitudes and other developmental areas of the child can be conducted.

c) This study is limited to quantitative data collection tools and to parents of children studying in Van. Studies can be conducted with parents of children studying in different regions, interviews can be conducted on parental attitudes and data diversity can be achieved. 